\title{
Macro Elements and Their Concentrations in the Blood Serum and Feed
}

\author{
Skalicka Magdaléna*, Nad Pavel and Bujnak Lukas \\ Institute of Nutrition, Dietetics and Feed Production, University of Veterinary Medicine and Pharmacy in Kosice, Slovakia
}

${ }^{\star}$ Corresponding author: Skalicka Magdaléna, Institute of Nutrition, Dietetics and Feed Production, University of Veterinary Medicine and Pharmacy in Kosice, Komenskeho 73, 04181 Kosice, Slovakia; E-mail: magdalena.skalicka@uvlf.sk

Received: September 20, 2019; Accepted: September 29, 2019; Published: October 06, 2019

\begin{abstract}
Within three years was analyzed mineral content $(\mathrm{Ca}, \mathrm{Mg})$ in feed and blood serum of dairy cows. Samples of serum and TMR - total mixed ratio, were from dairy farms $(\mathrm{n}=24)$ from different regions of Slovakia. In samples was determined average levels of the calcium $(\mathrm{Ca})$ and the magnesium $(\mathrm{Mg})$ according to the methodology used by the Official lists methods and laboratory diagnosis of food and feed. The significant increase (P $\leq .0 .05)$ of serum Ca level was found in cows in before calving in the B period and the statistical increase ( $\mathrm{P} \leq .0 .05)$ of the serum Ca level were recorded in dairy cows in after calving in period $\mathrm{C}$ with comparison to the dairy cows in period A. In the period top lactation in the period B was observed decrease the serum Ca $(33.8 \%)$ and in in the period $\mathrm{C}$ was decrease only $17.64 \%$. In the period antepartum and postpartum was a decrease the serum Ca between from 20.75 to $31.90 \%$. The serum magnesium in the period antepartum in the period B were decrease $38.03 \%$ and $8 \%$ decrease the serum $\mathrm{Mg}$ was in the period C - top lactation. Calcium and magnesium contens in TMR for dairy cows in production phases were in the range declared by the NRC (2001).
\end{abstract}

Key words: Atomic Absortion Spectrometer-AAS, Blood Serum, Calcium, Cows, Feed-TMR Total Mixed Ration For Dairy Cows, Mangnesium

\section{Introduction}

The amount of minerals in feed varies within a very wide range depending on ecological conditions, the composition of crops, the content of access nutrients in the soil, and the intensity of fertilization. The use of minerals from feed can be altered by the combination of feeds, but also by the intensity and the way of grass fertilization and the different representation of grasses, clover and herbs [1,2]. Mineral elements have crucial role in animal production and health. Minerals, in the form of chemical compounds, are naturally available through geological processes in the form of simple salts to very complex silicates [3]. Minerals are grouped into macrominerals, i.e. calcium $(\mathrm{Ca})$, magnesium $(\mathrm{Mg})$, sodium $(\mathrm{Na})$, potassium $(\mathrm{K})$, and phosphor $(\mathrm{P})$, and microminerals, i.e. iron $(\mathrm{Fe})$, copper $(\mathrm{Cu})$, zinc $(\mathrm{Zn})$, copper (Co), and manganese ( $\mathrm{Mn})$ [4]. Minerals have a special role in ensuring efficient growth, reproduction and immunocompetence in animals. Macrominerals are required in the development of bones and teeth and are also found in lipids, proteins, muscle, and tissue, while microminerals have a great impact on animal's reproductive physiology and its imbalance causes various problems leading to lower reproductive efficiency. Mineral level can also be used for rapid and accurate in-vivo classification of cattle according to organic and non-organic production type [5]. The dairy cow experiences most physiological stress during the transition period when it moves from the demands of fetal growth through to calving, colostrum production and, eventually, maximal milk production. In addition to these drains on the animal's physical resources, the cow must be in a suitable physiological state to ensure repair of any tissue damaged during calving, and to maintain resistance to disease challenges [6]. For high-quality control of health and nutrition status it is therefore necessary to gain detailed information about the changes in the internal environment during the individual stages of the productive life of animals [7]. Determination of indicators of the metabolic profile in course of the breeding season helps to diagnose the metabolic problems of the animals [8]. Cows' nutrition and feed technology belong to the external factors that affect their production. TMR - total mixwed ration (mixed feed) is considered to be the optimal way to provide a balanced amount of nutrients for dairy cows. It is a feeding system for dairy cows, the essence of which consists in the combination of bulk fodder, grain, protein, minerals, vitamins and various additives [9]. Of the voluminous feed, the lucerne, clover and hay are rich in calcium. The most calcium-containing silage contains clover and lucerne silage. The opposite value shows corn silage in which the calcium value is seven times lower. The magnesium content in feed plants depends on the magnesium content of the soil, the soil $\mathrm{pH}$ and the fertilizer application method [10]. When feeding dairy cows, the requirements of dairy cows must be taken into account, especially during the breeding cycle [11]. The aim of our work is to monitor the occurrence of calcium and magnesium in TMR and in the blood serum of dairy cows.

\section{Materials and Methods}

Within three years (first year A, second year B, third year C), the calcium $(\mathrm{Ca})$ and magnesium $(\mathrm{Mg})$ content of the blood serum of dairy cows and TMR were monitored. Feed samples - TMR and blood serum came from Slovak breeds of production dairy cows $(n=24)$. 
Samples of TMR $(\mathrm{A}-\mathrm{n}=30 ; \mathrm{B}-\mathrm{n}=36 ; \mathrm{C}-\mathrm{n}=36)$ and blood serum $(\mathrm{A}-\mathrm{n}=180 ; \mathrm{B}-\mathrm{n}=216 ; \mathrm{C}-\mathrm{n}=216) 21$ days before calving, -21 days after calving and at the peak of lactation. For the determination of mineral substances in samples of plant and biological material, the methodology used in the List of Official Methods and Laboratory Diagnostics of Food and Feed [11] was used.

Blood samples were collected in the morning via the jugular vein. After proper clotting, the blood samples were centrifuged at 3500 rpm for 15 minutes and the serum samples were stored at $-20^{\circ} \mathrm{C}$ until analyses. Before measuring, serum samples were deproteinized by supplementing trichloracetic acid at a 1:1 ratio. After centrifugation, the content of $\mathrm{Ca}$ and $\mathrm{Mg}$ in the supernatant was measured directly by using the flame method of an atomic absorption spectrometer (Unicam Solar, 939, Great Britain). Feed samples were processed by digestion in the microwave oven (MLS-1200 Mega, Milestone) by using $5 \mathrm{~mL}$ $\mathrm{HNO} 3$ and $1 \mathrm{~mL} \mathrm{HCl}$ per $1 \mathrm{~g}$ of sample. The program of digestion was as follow: 1st step-250 W, 2 minutes; 2nd step-0W, 2 minutes; 3rd step-250W, 5 minutes; 4th step-400 W, 5 minutes; 5 th step-500 $\mathrm{W}, 5$ minutes; and 6th step-600W, 2 minutes. The digested samples of feeders were analyzed for the presence of $\mathrm{Cu}$ and $\mathrm{Zn}$ by using the flame method of an atomic absorption spectrometer (Unicam Solar, 939, Great Britain). The flame conditions were those recommended by the instrument manufacturer for $\mathrm{Ca}$ and $\mathrm{Mg}$ (wavelength 422.7 and 285.2, respectively, band pass $0.5 \mathrm{~nm}$ ). The content of $\mathrm{Cu}$ and $\mathrm{Zn}$ in forage and blood were determined according to the methodology used by the Official lists methods and laboratory diagnosis of food and feed.

\section{Statistical Analysis}

The statistical evaluation of the results has been done by the program of microsoft Excel 7.0, using Student's t-test at $(\mathrm{P} \leq 0.05)$ and $(\mathrm{P} \leq 0.01)$ level of significance. For the calulation of means, values below the detection limits were set to zero. We compared the values from each of the three years $\mathrm{A}, \mathrm{B}$, and $\mathrm{C}$ and between the individual production phases.

\section{Results and Discussion}

\section{Calcium and Magnesium In Feed}

The observed amounts of calcium and magnesium in mixed feed - TMR samples over the reference period are summarized in Table 1. The mean contents of calcium in feed intended for dairy cows in before calving dairy cows in the periods A and B $(5.49 \pm 1.97,6.00 \pm 0.59 \mathrm{~g}$ $/ \mathrm{kg})$ were at tolerance values $(4.00-6.00 \mathrm{~g} / \mathrm{kg})$ reported by [12]. In the period C, the calcium content was slightly increased by $6.45 \pm 2.69$ $\mathrm{g} / \mathrm{kg}$. The decreased calcium content was recorded in the TMR after calving at each observation period (Table 1 ) and in the A period at the top of lactation $(6.93 \pm 1.16 \mathrm{~g} / \mathrm{kg})$ and in the period B $(5.93 \pm 1.34 \mathrm{~g} /$ $\mathrm{kg}$ ) compared to [12]. In the period $\mathrm{C}$ in feed intended for dairy cows at the peak of lactation $(7.47 \pm 2.09 \mathrm{~g} / \mathrm{kg})$, the amount of calcium was tolerated. In feed, in the B period was found the significant increase $(\mathrm{P} \leq 0.01)$ of the contents of $\mathrm{Mg}$ for dairy cows feeding in before calving in compared to the dairy cows from the period A. In the period C, in the feed was recorded the statistical increase $(\mathrm{P} \leq 0.05)$ of contents $\mathrm{Ca}$ in dairy cows feeding in top of lactation with comparison to the dairy cows from period B. Compared to the values reported by [13] in the curve samples of TMR (before calving $7.69 \mathrm{~g} / \mathrm{kg}$, after calving $8.88 \mathrm{~g}$ $/ \mathrm{kg}$ and at the top of lactation $8.49 \mathrm{~g} / \mathrm{kg}$ ), the values of calcium are lower. In India, [14] found average quantities of Ca $0.63 \%$ in mixed feeds for dairy cows that are similar to our findings. He pointed to a strong correlation between the calcium and magnesium content of the plants and the blood serum content of the dairy cows.

Table 1. The concentration of $\mathrm{Ca}$ and $\mathrm{Mg}$ in feed for dairy cows.

\begin{tabular}{|c|c|c|c|c|}
\hline \multicolumn{2}{|c|}{$g / k g$} & Before calving & After calving & Top of lactation \\
\cline { 2 - 5 } \multicolumn{2}{|c|}{} & $\mathbf{x} \pm \mathbf{s}$ & $\mathbf{x} \pm \mathbf{s}$ & $\mathbf{x} \pm \mathbf{s}$ \\
\hline \multirow{2}{*}{$\mathrm{A}$} & $\mathrm{Ca}$ & $5.49 \pm 1.97$ & $6.52 \pm 0.59$ & $6.93 \pm 1.16$ \\
\cline { 2 - 5 } & $\mathrm{Mg}$ & $3.17 \pm 0.76$ & $3.62 \pm 0.64$ & $3.87 \pm 1.17$ \\
\hline \multirow{2}{*}{$\mathrm{B}$} & $\mathrm{Ca}$ & $6.00 \pm 0.59$ & $6.75 \pm 1.38$ & $5.93 \pm 1.34$ \\
\cline { 2 - 5 } & $\mathrm{Mg}$ & $4.12 \pm 0.77 * *$ & $4.07 \pm 0.53$ & $4.10 \pm 0.75$ \\
\hline $\mathrm{C}$ & $\mathrm{Ca}$ & $6.45 \pm 2.69$ & $6.72 \pm 2.9$ & $7.47 \pm 2.09 *$ \\
\cline { 2 - 5 } & $\mathrm{Mg}$ & $3.94 \pm 1.49$ & $3.87 \pm 1.41$ & $4.18 \pm 0.62$ \\
\hline
\end{tabular}

$\mathrm{x}=$ mean concentrations; $\mathrm{s}=$ standard deviation; statistically significant $* \mathrm{p} \leq 0.05 ; * *$ $\mathrm{p} \leq 0.01$

Magnesium content in the TMR monitored was increased compared to NRC (2001). Increased amounts of magnesium were found in postpartum feed during periods $\mathrm{A}, \mathrm{B}$, and C $(3.62 \pm 0.64$, $4.07 \pm 0.53$ and $3.87 \pm 1.41 \mathrm{~g} / \mathrm{kg})$. In feed, in the B period was found the significant increase $(\mathrm{P} \leq 0.01)$ of the contents of $\mathrm{Mg}$ for dairy cows feeding in before calving in compared to the dairy cows from the period $\mathrm{A}$. In India, low levels of magnesium $(0.28 \% \mathrm{Mg})$ were found in mixed feed for dairy cows $[14,15]$ reported low levels of calcium in feed, where the soil had an adequate amount of calcium, and the magnesium concentration in the soils was below the critical level, but the feed was higher.

\section{Calcium and Magnesium In Blood Serum}

The mean levels of serum calcium found in the dairy cows before calving, after calving and top of lactation over the reference period were within the reference values $(2.25-3.00 \mathrm{mmol} / \mathrm{l})$ (Table 2). The significant increase $(\mathrm{P} \leq .0 .05)$ of serum $\mathrm{Ca}$ level was found in cows in before calving in the $\mathrm{B}$ period in comapred to the cows in the period A. Similarly, the statistical increase $(\mathrm{P} \leq .0 .05)$ of serum Ca level were recorded in dairy cows in after calving in period $\mathrm{C}$ with comparison to the dairy cows in period A. In the A period of the group of dairy cows that were in before calving, individual mild reductions in serum calcium were $31.9 \%$, and $30.9 \%$ after calving and $25.72 \%$ at the top of lactation. In period $\mathrm{B}$, individual serum calcium reduction was observed in $28.16 \%$ of dairy cows before calving, $23.4 \%$ after calving, and $33.6 \%$ of dairy cows at the top of lactation. A slight decrease in serum calcium was also observed in $\mathrm{C}$ period in the individual production stages of dairy cows ranging from $17.64 \%$ to $24.07 \%$ of dairy cows. Plasma Ca concentrations are reduced in early postpartum cows, because of increased demand of $\mathrm{Ca}$ for synthesis of milk coupled with the relativelyslow response in up-regulating $\mathrm{Ca}$ absorption from the intestinal tract. The postpartum depression in plasma and 
ionized $\mathrm{Ca}$ is greater in older cows [16]. [16,17] reported the lower concentration in blood serum of Ca of dairy cows in the individual production phases in compared to our results.

Table 2. The concentration of $\mathrm{Ca}$ nad $\mathrm{Mg}$ in blood serum of dairy cows.

\begin{tabular}{|c|c|c|c|c|}
\hline \multicolumn{2}{|c|}{$\mathbf{m m o l} / \mathrm{L}$} & before calving & after calving & top of lactation \\
\cline { 2 - 5 } \multicolumn{2}{|c|}{} & $\mathbf{x} \pm \mathbf{s}$ & $\mathbf{x} \pm \mathbf{s}$ & $\mathbf{x} \pm \mathbf{s}$ \\
\hline \multirow{2}{*}{$\mathrm{A}$} & $\mathrm{Ca}$ & $2,21 \pm 0.30$ & $2.28 \pm 0.31$ & $2.35 \pm 0.38$ \\
\cline { 2 - 5 } & $\mathrm{Mg}$ & $0.81 \pm 0.08$ & $0.78 \pm 0.10$ & $0.84 \pm 0.13$ \\
\hline \multirow{2}{*}{$\mathrm{B}$} & $\mathrm{Ca}$ & $2.39 \pm 0.27 *$ & $2.70 \pm 0.72$ & $2.41 \pm 0.41$ \\
\cline { 2 - 5 } & $\mathrm{Mg}$ & $0.87 \pm 0.28$ & $0.80 \pm 0.16$ & $0.87 \pm 0.19$ \\
\hline \multirow{2}{*}{$\mathrm{C}$} & $\mathrm{Ca}$ & $2,42 \pm 0,46$ & $2,34 \pm 0,4$ & $2,40 \pm 0,30$ \\
\cline { 2 - 5 } & $\mathrm{Mg}$ & $0,87 \pm 0,14$ & $0,88 \pm 0,15 *$ & $0,90 \pm 0,10$ \\
\hline
\end{tabular}

$\mathrm{x}=$ mean concentrations; $\mathrm{s}=$ standard deviation; statistically significant $* \mathrm{p} \leq 0.05$.

Similarly, mean serum magnesium levels in the reference period in dairy cows ranged within the reference values $(0.74-1.23 \mathrm{mmol} / \mathrm{l})$. We observed a decrease in serum magnesium in period $\mathrm{A}$ and $\mathrm{B}$ in individual production, before claving $35.2 \%$ and $38.03 \%$, after calving $29.55 \%$ and $37.41 \%$, top of lactation $22.72 \%$ and $19.12 \%$, respectively. In period $\mathrm{C}$, the reduction in serum magnesium over the reference values was lower than $8 \%$ for dairy cows in the individual production phases. The observed slight decrease in serum calcium in the production phases in some dairy cows in the studied holdings revealed hypocalcaemia. Hypokalaemia occurs with increased colostrum formation. Insufficient parathyroid hormone concentration and decreased receptor activity for calcium in the gut and bones is not enough to keep blood calcium levels within physiological limits. Concurrent changes in magnesium concentration and disruption of $\mathrm{Ca} / \mathrm{Mg}$ ratios occur. Disturbance of the mutual relationships of minerals, especially calcium and magnesium, causes CNS disorders, circulatory and energetic metabolism $[18,19,20]$. Some papers present concentrations of biochemical parameters in the blood of cows at different stages of lactation; their comparison is limited as the values are determined by different methods. They have a different number of animals, with different genetic equipment and kept under different conditions $[17,18,21]$.

\section{Conclusion}

In conclusion, at work we monitored calcium and magnesium content in feed and blood serum of dairy cows in selected breeds of $d$ airy cows for three years. Mineral deficiency in dairy cows can be the primary cause of many metabolic and production disorders. This study revealed some differences in blood serum. Reduction of serum calcium in production phases in dairy cows, the initial stage of hypocalcaemia in dairy cows. By following the principles of differentiated feeding of dairy cows by production phases and by monitoring the levels of minerals in blood serum and feed, avoid metabolic and production disorders.

\section{References}

1. Bulletin of the Ministry of Agriculture SR (2004) Listing the Official Methods of Laboratory Diagnostics of Food and Feed: 339.

2. Galik B, Biro D, Juracek M, Simko M, Ulman I (2010). The effect of different silage additives on macroelement concentration in Alfalfa silage. Krmiva 52: 183-188.

3. Khan Z I, Ahmed K, Ashraf M, Valeem E E, Javed I (2008) A comparative study on mineral status of blood plasma of small ruminants and Pastures in Punjab, Pakistan. Pak. J Bot 41: 67-72.

4. Maradal A B, Yadav P S, Vanita K (2004) Mineral status of buffaloes under farm feeding condition of Faridabad district of Haryana state. Indian J Anim Nutr 21: 104-110.

5. Rodriguez-Bermudez R, Herrero-Latorre C, Lopez-Alonso M, Losada DE, Iglesias $\mathrm{R}$, et al. (2018) Organic cattle products: Authenticating production origin by analysis of serum mineral content. Food Chem 264: 210-217.

6. Andrieu S (2008) Is there a role for organic trace element supplements in transition cow health? Vet $J$ 176: 77-83.

7. Cavestany D, Blanc J E, Kulcsar M, Uriarte G, Chilibroste P, Meikle A et al. (2005) Studies of the transition cow under a pasture-based milk production system: metabolic profiles. J Vet Med Series A-Physiology Pathology Clinical Medicine 52: $1-7$.

8. Verheyen A J N, Maes D G D, Mateusen B, Deprez P, Janssens G P J, De Lange L et al. (2007) Serum biochemical reference values for gestating and lactating cows. Vet $J$ 174: 92-98.

9. Robinson PH, Meyer D (2010) Total Mixed Ration (TMR) Sampling Protocol, California : UCANR Publications, 14.

10. Biro D (2010) Feeding of ruminants (book). Nitra, Slovak republic: Publishing Slovak Agricultural University, 135.

11. Tancin V (2013) Livestock farming in marginal areas (Slovak language), Nitra, The Slovak republic. Center for animal research, 70 .

12. NRC 2001: Nutrient Requirements of Dairy Cattle. 7th Rev. Ed. National Research Council. Nat. Acad. Sci., Washington, DC. USA.

13. Skalicka M, Maskalova I, Vajda V (2010) Relationship nutritional levels and levels of mineral metabolism in peripartum dairy cows and the production phase. Proceedings Lazar days of nutrition and veterinary dietetics 9: 73-76.

14. Kumaresan A, Bujarbaruah KM, Pathak KA, Brajendra, Ramesh T (2010) Soilplant-animal continuum in relation to macro and micro mineral status of dairy catle in subtropical hill. Trop Anim Health Prod 42: 569-577.

15. Ashraft MY, Khan A, Ashraft, Zafar S (2006) Studies on transfer of mineral nutrients from feed, water, soil and plants to buffaloes inder arid environments. $J$ Arid Environ 65: 632-643.

16. Filipejova T, Kovacik J, Kovacik A, Bulla J (2010) Mineral profile of dairy cows from blood plasma and urine. Animal Physiology 2010 : proceedings of international conference 89-91.

17. Slosarkova S, Dulicek J, Fleischer P (2010) Concentration of selected blood biochemistry parameters in Holstein cows during important stages of lactation. Animal Physiology 2010: proceedings of international conference: 415-424.

18. Illek J (2014) Metabolic profiles in cattle and their interpretation (Metabolicke profily u skotu a jejich interpretace Czech language). Proceedings of lectures XIV. Kongres Chamber of Veterinary Surgeons of the Slovak Republic, Jasna, Demänovska Valley, Slovakia 30: 99-100.

19. Pavlata L, Pechova R, Dvorak R (2008) Diferencialni diagnostika syndromu ulehnuti u krav. (Differential diagnosis of cow's bedding syndrome ) Veterinarstvi 58: $43-51$.

20. Dorszewski P, Grabowicz M, Mikolajczak J ( 2006) Usefulness of various biological additions for ensiling green fodder of alfalfa. Polish J Nat Sci 3: 45-52.

21. Marenjak T S, Poljicak Milas N, Zdelar-Tuk M (2006) Auswirkungen von Fütterung und Klima auf Milchleistung und biochemiches Blut und Milchprofil. Tierarztl. 61: $357-362$.

Citation:

Skalicka Magdaléna, Nad Pavel and Bujnak Lukas (2019) Macro Elements and Their Concentrations in the Blood Serum and Feed. Integr J Vet Biosci Volume 3(2): 1-3. 